\title{
THE
}

\section{Effect of Saturable Serum Protein Binding on the Pharmacokinetics of Unbound Cefonicid in Humans}

\author{
Michael N. Dudley \\ University of Rhode Island \\ C. Shyu \\ C. H. Nightingale \\ R. Quintiliani
}

Follow this and additional works at: https://digitalcommons.uri.edu/php_facpubs

Terms of Use

All rights reserved under copyright.

\section{Citation/Publisher Attribution}

Dudley, M. N., Shyu, W. C., Nightingale, C. H., \& Quintiliani, R. (1986). Effect of Saturable Serum Protein Binding on the Pharmacokinetics of Unbound Cefonicid in Humans. Antimicrobial Agents and Chemotherapy, 30(4), 565-569. doi: 10.1128/AAC.30.4.565

Available at: http://dx.doi.org/10.1128/AAC.30.4.565

This Article is brought to you for free and open access by the Pharmacy Practice at DigitalCommons@URI. It has been accepted for inclusion in Pharmacy Practice Faculty Publications by an authorized administrator of DigitalCommons@URI. For more information, please contact digitalcommons-group@uri.edu. 


\title{
Effect of Saturable Serum Protein Binding on the Pharmacokinetics of Unbound Cefonicid in Humans
}

\author{
MICHAEL N. DUDLEY, ${ }^{1,2,3 *}$ WEN-CHYI SHYU ${ }^{2,4}+$ CHARLES H. NIGHTINGALE, ${ }^{2,4}$ \\ AND RICHARD QUINTILIANI ${ }^{1,5}$ \\ Division of Infectious Diseases ${ }^{1}$ and Department of Pharmacy, ${ }^{2}$ Hartford Hospital, Hartford, Connecticut 06115; Schools \\ of Medicine ${ }^{5}$ and Pharmacy, ${ }^{4}$ University of Connecticut, Storrs, Connecticut 06268; Department of Pharmacy and \\ Division of Infectious Diseases, Roger Williams General Hospital, Providence, Rhode Island 02908; and University of \\ Rhode Island College of Pharmacy, Providence, Rhode Island 02881-0809 3
}

Received 24 February 1986/Accepted 10 July 1986

\begin{abstract}
Previous studies have demonstrated high, concentration-dependent serum protein binding of cefonicid. To determine the in vivo pharmacokinetic significance of these observations, the pharmacokinetics of both total and unbound (non-protein-bound) cefonicid was studied in six volunteers after a single intravenous dose of 30 $\mathrm{mg} / \mathrm{kg}$. Saturable serum protein binding was observed in vivo; the mean \pm standard deviation free fraction of cefonicid was $17.6 \pm 6.1 \%$ immediately after administration and declined to a constant value of approximately $2 \%$ as total serum concentrations fell below $100 \mu \mathrm{g} / \mathrm{ml}$. This nonlinear binding was associated with a pronounced decline in unbound serum cefonicid concentrations during the first $3 \mathrm{~h}$ after administration, with low or undetectable unbound drug concentrations by $12 \mathrm{~h}$. Renal clearance of total cefonicid averaged 21.1 $\mathrm{ml} / \mathrm{min}$ per $\mathrm{kg}$ and did not vary with time; in contrast, the mean \pm standard deviation unbound cefonicid renal clearance increased from $5.7 \pm 2.1$ to $10.8 \pm 1.6 \mathrm{ml} / \mathrm{min}$ per $\mathrm{kg}$ with time $(P<0.02)$. This study may partially explain the poor results obtained with single daily dosing of cefonicid in endocarditis. Dosage regimens of certain antimicrobial agents with high, saturable serum protein binding and extensive renal tubular secretion may be most appropriately designed based on unbound drug pharmacokinetics.
\end{abstract}

Binding of drugs to plasma proteins is often a significant determinant of the pharmacological properties of antimicrobial agents. The proportional reduction in the in vitro activity of antimicrobial agents highly bound to plasma proteins in media supplemented with serum has been noted for several beta-lactam and other compounds $(4,19)$. Protein binding may influence the pharmacokinetics of non-protein-bound (unbound) as well as total (bound and unbound) drug by affecting the rate of excretion or altering the rate and extent of drug distribution from blood to tissues $(3,7,18)$.

The extent of binding of drugs to protein is determined by drug and protein concentration, the affinity of drug for the protein, and the number of binding sites on each molecule of protein (9). For some drugs, clinically achievable concentrations in vivo may saturate binding sites on plasma proteins, resulting in a free fraction of drug larger than that observed at lower drug concentrations (9). As drug concentrations decline in vivo due to drug excretion, the free-fraction declines and approaches a constant value. This nonlinearity in in vivo plasma protein binding may affect the decline in total and unbound drug concentrations because of the dependence of the volume of distribution and clearance of total and unbound drug on the extent of plasma protein binding (3, $7,17)$.

Cefonicid is a cephalosporin antibiotic highly bound to plasma proteins (approximately $96 \%$ at $100 \mu \mathrm{g} / \mathrm{ml}$ ) (5). We have previously demonstrated saturable serum protein binding in vitro, with the fraction bound to protein decreasing to as low as $67 \%$ with drug concentrations exceeding $400 \mu \mathrm{g} / \mathrm{ml}$ (W. C. Shyu, M. N. Dudley, C. H. Nightingale, and R.

\footnotetext{
* Corresponding author.

$\dagger$ Present address: Department of Metabolism and Pharmacokinetics, Bristol-Myers Co., Syracuse, NY 13221-4755.
}

Quintiliani, 35th National Meeting of the Academy of Pharmaceutical Sciences, 1983). Pharmacokinetic data obtained in volunteers receiving a single intravenous dose of 0.5 to 1 $\mathrm{g}$ of cefonicid intravenously have demonstrated high serum concentrations and slow renal elimination (serum elimination half-life, approximately $4 \mathrm{~h}$ ) (5). In view of the high, concentration-dependent plasma protein binding of cefonicid in vitro, the in vivo serum protein binding and disposition of total and unbound cefonicid after a single large dose was studied in humans.

\section{MATERIALS AND METHODS}

Subjects. Six healthy volunteers (four men, two women) ranging between 24 and 30 years of age participated in the study. The mean \pm standard deviation (SD) weight and creatinine clearance (based on a 24-h urine collection) were $68.8 \pm 11.3 \mathrm{~kg}$ and $127 \pm 10.2 \mathrm{ml} / \mathrm{min}$, respectively. All of the following prestudy laboratory tests were within normal limits: complete blood count, total serum protein, albumin, aspartate aminotransferase, alanine aminotransferase, total and indirect bilirubin, creatinine, and blood urea nitrogen. All subjects fasted for $12 \mathrm{~h}$ before and $4 \mathrm{~h}$ after drug infusion. No medications or alcohol were ingested for $48 \mathrm{~h}$ before drug administration. All volunteers gave their written informed consent according to the guidelines of our institution.

Dosing and sample collection. Each subject received a single 5-min intravenous bolus infusion of $30 \mathrm{mg}$ of cefonicid per $\mathrm{kg}$ in $50 \mathrm{ml}$ of $5 \%$ glucose solution (Monocid; Smith Kline \& French Laboratories, Philadelphia, Pa.). Samples of venous blood ( 7 to $10 \mathrm{ml}$ ) were collected at the following times: $0,5,10,15,20,30,45,60,75$, and $90 \mathrm{~min}$ and 2, 2.5, $3,3.5,4,5,6,8,12$, and $24 \mathrm{~h}$ after the dose. Blood samples were collected from an indwelling intravenous catheter during the first 8 to $12 \mathrm{~h}$ and then by direct venipuncture. 


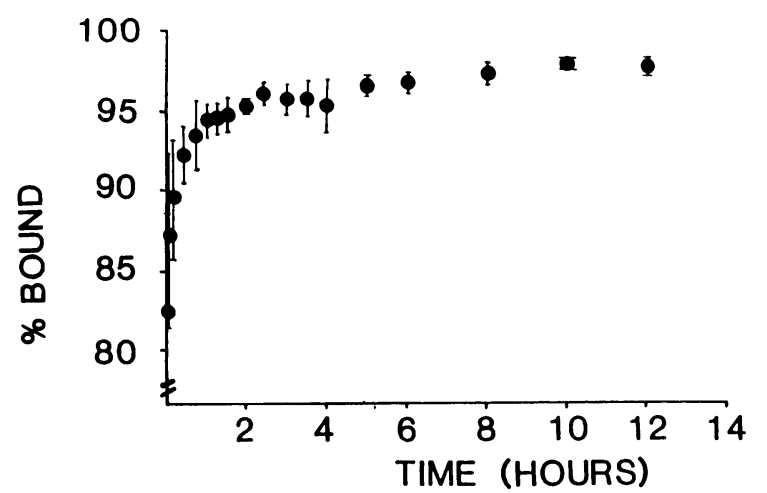

FIG. 1. Change in serum protein binding of cefonicid in vivo as a function of time after a single intravenous dose of $30 \mathrm{mg} / \mathrm{kg}$ in six volunteers. Vertical lines indicate means \pm SDs.

Normal saline was used to flush intravenous catheters to maintain patency. Urine was collected, the volume was measured, and a sample was saved during the following intervals: 0 to 30,31 to 60,61 to 90 , and 91 to $120 \mathrm{~min}$ and 2 to $2.5,2.5$ to 3,3 to $3.5,3.5$ to 4,4 to 5,5 to 6,6 to 8,8 to 10,10 to 12,12 to 24,24 to 36 , and 36 to $48 \mathrm{~h}$ after administration of the dose. Urine was frozen at $-80^{\circ} \mathrm{C}$ until the assay.

Unbound drug. Blood samples from volunteers were allowed to clot and centrifuged, and the serum was harvested. Unbound drug was immediately separated by ultrafiltration of a portion of each serum sample with an MPS-1 unit with a YMT membrane (Amicon Corp., Danvers, Mass.) through centrifugation at $1,700 \times g$ for $15 \mathrm{~min}$ at $37^{\circ} \mathrm{C}$. Analysis of binding properties in preliminary experiments demonstrated that binding of cefonicid to serum proteins was rapid and not time dependent. Validation studies also showed no degradation of cefonicid after incubation at $37^{\circ} \mathrm{C}$ in serum (data not shown). Binding to the YMT membrane was checked by ultrafiltration of an aqueous standard; complete recovery of drug was observed in the ultrafiltrate. Serum and ultrafiltrate were stored at $-80^{\circ} \mathrm{C}$ until the assay.

Assay. Cefonicid concentrations in serum, serum ultrafiltrate, and urine were measured by microbiological assay with Bacillus subtilis (Difco Laboratories, Detroit, Mich.)seeded agar plates and paper disks spotted with $15 \mu \mathrm{l}$ of sample or standard. Standards $(12.5$ to $400 \mu \mathrm{g} / \mathrm{ml})$ for assay of total cefonicid concentrations in serum were prepared from pooled serum collected from drug-free healthy volunteers. Standards for the assay $(1.25$ to $50 \mu \mathrm{g} / \mathrm{ml})$ of unbound serum and urine cefonicid concentrations were prepared in Sorenson phosphate buffer. The lower limit of assay sensitivity was $12 \mu \mathrm{g} / \mathrm{ml}$ in serum and $0.8 \mu \mathrm{g} / \mathrm{ml}$ in buffer. Standard curves of the zone size versus the natural logarithm of the drug concentration were linear in the ranges listed above with correlation coefficient $(r)$ values greater than 0.99 on all days. The within-day coefficient of variation for the assay ranged between 6 and $15 \%$ for serum standards $(n=6)$ and 10 to $17 \%$ for buffer standards $(n=15)$. Drug content in the ultrafiltrate below the limit of sensitivity of the microbiologial assay was assayed with high-pressure liquid chromatography (15).

Data analysis. The number of binding sites per mole of albumin and the affinity of cefonicid for binding sites was determined by nonlinear regression (14) of binding data using the equation

$$
r=\frac{n \times k a[D f]}{1+k a[D f]}
$$

where $r$ is the number of moles of drug bound to moles of protein, $n$ is the number of binding sites of a given type per mole of protein, $k a$ is the association constant between drug and protein, and $D f$ is the molar concentration of free drug (9).

Total and unbound serum concentration versus time data were analyzed by noncompartmental pharmacokinetic methods (8). The time-averaged free fraction of cefonicid in the body $(\overline{f p})$ after the dose was determined by (13)

$$
\overline{f p}=\frac{\mathrm{AUC}^{U}}{\mathrm{AUC}^{T}}
$$

where $\mathrm{AUC}^{U}$ and $\mathrm{AUC}^{T}$ are the areas under the serum concentration-versus-time curve from time 0 to infinity for unbound and total drug, respectively. Areas were calculated by the linear trapezoidal rule. The total body clearance of total $\left(\mathrm{CL}^{T}\right)$ and unbound $\left(\mathrm{CL}^{U}\right)$ drug was determined by dose/AUC ${ }^{T}$ or dose/AUC ${ }^{U}$, respectively. The volume of distribution of total drug at steady state $\left(V^{T}{ }_{\text {ss }}\right)$ was determined by

$$
V_{\text {ss }}^{T}=\frac{\text { dose } \times \mathrm{AUMC}^{T}}{\mathrm{AUC}^{T}}-\frac{\text { dose } \times t^{\prime}}{2 \times \mathrm{AUC}^{T}}
$$

where $\mathrm{AUMC}^{T}$ is the area under the first moment of the plasma concentration of total drug-versus-time curve from time 0 to infinity (calculated using the linear trapezoidal rule) and $t^{\prime}$ is the time of drug infusion. The volume of distribution of unbound drug at steady state $\left(V^{U}{ }_{\text {ss }}\right)$ was calculated by (13)

$$
V_{\text {ss }}^{U}=V_{\text {ss }}^{T} / \sqrt[f p]{ }
$$

The terminal slope $(\lambda z)$ was identified by visual inspection and calculated by unweighted least-squares linear regression. The half-life $\left(t_{1 / 2} \lambda z\right)$ was calculated by division of this value into $\ln 2$.

The renal clearance of total $\left(\mathrm{CL}_{\mathrm{R}}^{T}\right)$ or unbound $\left(C L_{\mathrm{R}}{ }_{\mathrm{R}}\right)$ was calculated by

$$
\mathrm{CL}^{T}{ }_{\mathrm{R}} \text { or } \mathrm{CL}_{\mathrm{R}} U_{\mathrm{R}}=\frac{A e_{\left(t_{1}-t_{2}\right)}}{\mathrm{AUC}^{T \text { or } U_{\left(t_{1}-t_{2}\right)}}}
$$

where $A e\left(t_{1}-t_{2}\right)$ is the amount of drug excreted unchanged in the urine during the interval $t_{1}$ to $t_{2}$ and $\mathrm{AUC}^{T}$ or $U\left(t_{1}-t_{2}\right)$ is the area under the corresponding total or unbound serum drug concentration curve during the same interval. The renal clearance values and total or unbound drug during the various collection intervals were compared by analysis of variance with repeated measures.

\section{RESULTS}

Figure 1 depicts the serum protein binding of cefonicid as a function of time in six volunteers. Saturable serum protein binding was observed. The mean \pm SD percentage of free cefonicid was $17.6 \pm 6.1 \%$ immediately after administration and declined to $4.2 \pm 0.9 \%$ by 3 h postadministration. Serum protein binding approached a constant value of $98 \%$ as total concentrations declined below $100 \mu \mathrm{g} / \mathrm{ml}$, approximately $8 \mathrm{~h}$ postadministration. Kinetic analysis of binding data in all subjects revealed only one class of binding sites for cefonicid, with a mean \pm SD of $0.96 \pm 0.16$ binding sites per 


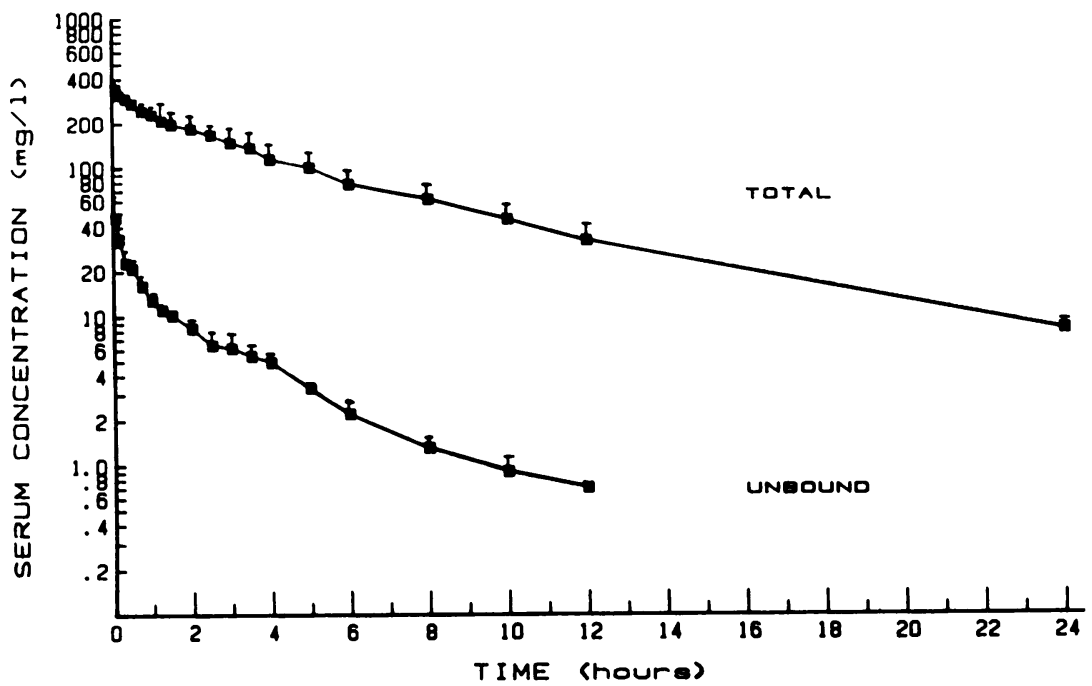

FIG. 2. Mean + SD total and unbound serum cefonicid concentrations versus time plot for six volunteers after a single intravenous dose of $30 \mathrm{mg} / \mathrm{kg}$.

mol of albumin. The mean \pm SD affinity constant $(k a)$ of cefonicid for these sites was $5.7 \times 10^{4} \pm 2.0 \times 10^{4}$ per $\mathrm{M}$.

The decline in mean total and unbound serum cefonicid concentration is depicted in Fig. 2. Total serum drug concentrations were high, with a mean \pm SD peak concentration of $341 \pm 44.3 \mu \mathrm{g} / \mathrm{ml}$ immediately after dose administration. After a rapid distribution phase, total serum concentrations declined slowly, with a mean \pm SD serum elimination half-life of $4.1 \pm 0.8 \mathrm{~h}$. In contrast, unbound serum concentrations declined rapidly and in a prolonged nonlinear manner; the mean $\pm S D$ peak unbound serum cefonicid concentration was $46.2 \pm 22.9$ after administration and declined to $12.8 \pm 2.1 \mu \mathrm{g} / \mathrm{ml}$ within $1 \mathrm{~h}$ after administration. At $12 \mathrm{~h}$, serum concentrations were less than $1 \mu \mathrm{g} / \mathrm{ml}$ in all subjects.

The pharmacokinetic analysis of total and unbound serum cefonicid concentrations is summarized in Table 1. Values of total body and renal clearance and volume of distribution at steady state were substantially greater for unbound drug than for total drug.

The renal clearance of total and unbound cefonicid during 10 time intervals is shown in Fig. 3. The renal clearance of unbound cefonicid increased with time, with mean \pm SD values increasing from $5.7 \pm 2.1 \mathrm{ml} / \mathrm{min}$ per $\mathrm{kg}$ during the first hour after dosing to $10.8 \pm 1.6 \mathrm{ml} / \mathrm{min}$ per $\mathrm{kg}$ between 8 and $10 \mathrm{~h}$ postadministration. The change in the renal clearance of unbound cefonicid with time was statistically significant $(P<0.02$, analysis of variance $)$. In contrast, the renal clearance of total cefonicid during these intervals did not vary with time $(P>0.05$, analysis of variance; Fig. 3$)$. The mean \pm SD percentage of the dose recovered unchanged in urine was $94.2 \pm 6.4 \%$.

\section{DISCUSSION}

The clinical and pharmacological importance of the nonprotein-bound, pharmacologically active fraction of drug in vivo has recently been reviewed (12). In antimicrobial chemotherapy, the influence of plasma protein binding on pharmacological issues such as tissue distribution and in vitro activity have been well studied, but only a few studies have compared the concentration-time profiles of unbound and total drug in humans $(16,21)$. Moreover, data from the present study as well as other in vivo studies (21) and computer simulations (17) demonstrate the marked effects of in vivo saturation of serum proteins on the disposition of total and unbound drug.

The concentration-dependent serum protein binding of cefonicid was marked, with binding characteristics similar to those observed in a previous in vitro study $\left(k a=6.4 \times 10^{4}\right.$ per M; Shyu et al., 35th National Meeting of the Academy of Pharmaceutical Sciences, 1983). The affinity of cefonicid to serum proteins in vitro and in vivo is higher than that reported for ceforanide (20), methicillin, and nafcillin (10); these drugs do not appear to have concentration-dependent protein binding at serum concentrations observed in humans. However, the affinity of cefonicid for plasma proteins was similar to that observed for ceftriaxone, a drug showing concentration-dependent binding similar to that of cefonicid (21).

TABLE 1. Pharmacokinetic parameters (mean \pm SD) of total and unbound cefonicid in six volunteers ${ }^{a}$

\begin{tabular}{lccccc}
\hline \multirow{2}{*}{ Cefonicid } & $\begin{array}{c}\text { Peak concn } \\
(\mu \mathrm{g} / \mathrm{ml})\end{array}$ & $\mathrm{AUC}_{0-x}(\mathrm{mg} \cdot \mathrm{h} / \mathrm{liter})$ & \multicolumn{2}{c}{ Clearance, $\mathrm{ml} / \mathrm{min}(\mathrm{ml} / \mathrm{min} \mathrm{per} \mathrm{kg)}$} & \multirow{2}{*}{$V_{s s}$, liters (liters/kg) } \\
\cline { 4 - 5 } & & & \multicolumn{1}{c}{ Total body } & \multicolumn{1}{c}{ Renal } \\
\hline Total & $324.7 \pm 46.4$ & $1,559.3 \pm 301.4$ & $22.4 \pm 3.0(0.33 \pm 0.07)$ & $21.1 \pm 3.2(0.32 \pm 0.08)$ & $7.0 \pm 1.1(0.10 \pm 0.01)$ \\
Unbound & $46.2 \pm 22.9$ & $67.2 \pm 8.6$ & $517^{b} \pm 85(7.6 \pm 1.1)$ & $486^{b} \pm 77(7.2 \pm 1.3)$ & $168^{b} \pm 54(2.41 \pm 0.7)$ \\
\hline
\end{tabular}

\footnotetext{
${ }^{a}$ See the text for explanation of abbreviations.

$b$ Time-averaged values due to nonlinear protein binding.
} 


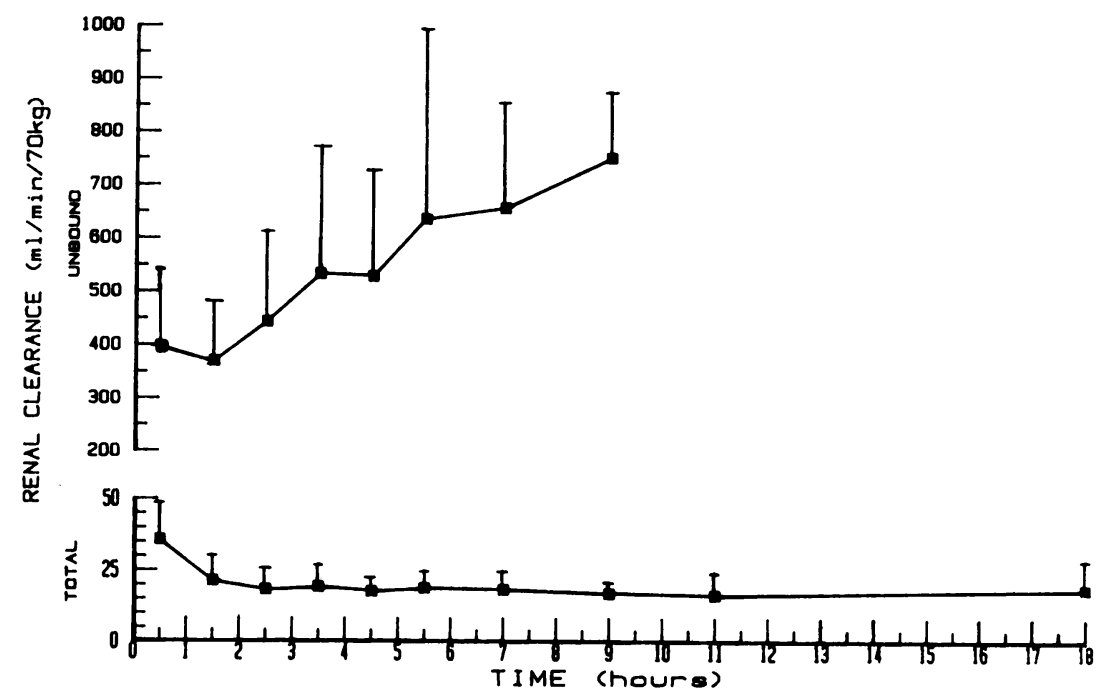

FIG. 3. Mean + SD renal clearance of total and unbound cefonicid as a function of time in six volunteers. The increase in renal clearance of unbound cefonicid with time was statistically significant $(P<0.02$, repeated measures analysis of variance).

The distribution and excretion rate of total cefonicid was similar to that reported by others using smaller or similar doses (5). In contrast to total serum concentrations, unbound serum cefonicid concentrations declined rapidly and in parallel with changes in the free fraction of drug in vivo. Although unbound drug concentrations could be measured up to $12 \mathrm{~h}$ in only three subjects, the half-life of the terminal slopes of unbound and total drug concentration-versus-time curves 8 to $12 \mathrm{~h}$ postadministration $(3.5 \pm 0.2 \mathrm{~h}$ for unbound drug versus $4.1 \pm 0.8 \mathrm{~h}$ for total drug) appeared to become parallel (Fig. 2). This is consistent with the simulations performed by Øie et al. (17). The large change in the free fraction of unbound cefonicid (approximately an eightfold reduction over a 12 -h period) resulted in a statistically significant increase in the renal clearance of unbound cefonicid during that time interval.

Despite similar binding characteristics, the effects of saturable in vivo serum protein binding on the renal excretion of unbound and total cefonicid are in sharp contrast to that observed for ceftriaxone. Stoekel et al. (21) demonstrated no change in unbound renal ceftriaxone clearance but a statistically significant decrease in total ceftriaxone renal clearance with time. The differences in the time dependence of the renal excretion rate of these drugs may be explained by the models of renal clearance proposed by Levy (11) and Dudley and Nightingale (3). Assuming that the renal tubular secretion rate of cephalosporins is a function of the total drug concentration, the renal clearance of total drug may be described by

$$
\mathrm{CL}_{\mathrm{R}}^{T}=(1-F)[(f u \times \mathrm{GFR})+\mathrm{CLs}]
$$

where $F$ is the fraction of drug reabsorbed, GFR is the glomerular filtration rate, $f u$ is the fraction unbound, and CLs is the renal secretion clearance or $\left(Q \times \mathrm{CL}_{I}\right) /\left(Q+\mathrm{CL}_{1}\right.$, where $Q$ is the plasma flow to renal tubular secretion sites, and $C_{\mathrm{I}}$ is the intrinsic renal secretion clearance referenced to total drug (11).

Division of equation 6 by $f u$ would define the renal clearance of unbound drug

$$
\mathrm{CL}_{\mathrm{R}}=(1-F)[\mathrm{GFR}+(\mathrm{CLs} / f u)]
$$

Cefonicid appears to undergo extensive renal tubular secre- tion in humans, with glomerular filtration accounting for only a small part of the renal excretion (3). Under these conditions, equation 6 may be reduced to

$$
\mathrm{CL}_{\mathrm{R}}{ }_{\mathrm{R}}=(1-F) \mathrm{CLs}
$$

and equation 7 may be reduced to

$$
\mathrm{CL}_{\mathrm{R}}=(1-F)(\mathrm{CLs} / f u)
$$

Therefore, reduction in the free fraction $(f u)$, which occurs with time after dosing (Fig. 1), would be expected to result in little change in total renal clearance and an increase in unbound renal clearance; this is consistent with Fig. 3. In contrast, ceftriaxone undergoes little or no renal tubular secretion (3). The renal clearance of ceftriaxone may thus be expressed as

$$
\mathrm{CL}_{\mathrm{R}}^{T_{\mathrm{R}}}=(1-F) \times f u \times \mathrm{GFR}
$$

and

$$
\mathrm{CL}_{\mathrm{R}} U_{\mathrm{R}}=(1-F) \mathrm{GFR}
$$

Therefore, changes in the free fraction would be expected to have no effect on the renal clearance of unbound ceftriaxone and result in a decrease in the renal clearance of total ceftriaxone with time. These predictions agree with the observations noted by Stoekel and colleagues (21). Thus, it appears that cephalosporins with a high degree of renal tubular secretion and high, saturable protein binding would be expected to have nonlinear excretion of the unbound, pharmacologically active drug and linear excretion of total drug.

These data may partially explain the poor clinical results of single daily administration of cefonicid in the treatment of tricuspid valve endocarditis due to Staphylococcus aureus (2). Our data demonstrate that serum concentrations of unbound, pharmacologically active cefonicid would exceed the MBC for the isolates reported by Chambers et al. (2) only transiently or not at all. Although some cephalosporins have been shown to exert a postantibiotic effect against $S$. aureus (approximately $2.5 \mathrm{~h}$ ) (1), it is unlikely that the total duration of bactericidal activity was sufficient to eradicate valve infection (6). This experience and the present study suggest that more frequent administration of cefonicid is necessary 
for the treatment of serious infections due to moderately susceptible organisms, such as $S$. aureus.

\section{LITERATURE CITED}

1. Bundtzen, R. W., A. U. Gerber, D. L. Cohn, and W. A. Craig. 1981. Post-antibiotic suppression of bacterial growth. Rev. Infect. Dis. 3:28-34.

2. Chambers, M. F., J. Mills, T. A. Drake, and M. A. Sande. 1984. Failure of a once-daily regimen of cefonicid for treatment of endocarditis due Staphylococcus aureus. Rev. Infect. Dis. 6(Suppl. 4):S870-S874.

3. Dudley, M. N., and C. H. Nightingale. 1982. Effects of protein binding on the pharmacology of cephalosporins, p. 227-239. In H. C. Neu (ed.), New beta-lactam antibiotics: a review from chemistry to clinical efficacy of the newer cephalosporins. Francis Clark Wood Institute for the History of Medicine, Philadelphia.

4. Dudley, M. N., C. H. Nightingale, R. Quintiliani, and R. Tilton. 1983. In vitro activity of cefonicid, ceforanide, and cefazolin against Staphylococcus aureus and Staphylococcus epidermidis and the effect of human serum. J. Infect. Dis. 148:178.

5. Dudley, M. N., R. Quintiliani, and C. H. Nightingale. 1984. Review of cefonicid, a long-acting cephalosporin. Clin. Pharm. 3:23-32.

6. Gengo, F. M., T. W. Mannion, C. H. Nightingale, and J. J. Schentag. 1984. Integration of pharmacokinetics and pharmacodynamics of methicillin in curative treatment of experimental endocarditis. J. Antimicrob. Chemother. 14:619-631.

7. Gibaldi, M., and J. R. Koup. 1981. Pharmacokinetic conceptsdrug binding, apparent volume of distribution, and clearance, Eur. J. Clin. Pharmacol. 20:299-305.

8. Gibaldi, M., and D. Perrier. 1982. Pharmacokinetics, 2nd ed., Marcel Dekker, Inc., New York.

9. Goldstein, A. 1949. The interaction of drugs and plasma proteins. Pharmacol. Rev. 1:102-165.

10. Joos, R. W., and W. H. Hall. 1969. Determination of binding constants of serum albumin for penicillin. J. Pharmacol. Exp.
Ther. 166:113-118.

11. Levy, G. 1980. Effect of plasma protein binding on renal clearance of drugs. J. Pharm. Sci. 9:482-483.

12. Levy, R. 1984. Rationale for monitoring free drug levels. Clin. Pharmacokinet. 9(Suppl. 1):1-9.

13. McNamara, P. J., M. Gibaldi, and K. Stoekel. 1983. Volume of distribution terms for a drug (ceftriaxone) exhibiting concentration-dependent protein binding. I. Theoretical considerations. Eur. J. Clin. Pharmacol. 25:399-405.

14. Metzler, C. M., G. L. Elfring, and A. J. McEwen. 1974. A user's manual for NONLIN and associated programs. The Upjohn Co., Kalamazoo, Mich.

15. Nightingale, C. H., R. Quintiliani, M. N. Dudley, P. Gough, M. Hickingbotham, N. S. Jordan, D. Rose, and M. Toscani. 1984. Tissue penetration and half-life of cefonicid. Rev. Infect. Dis. 6(Suppl. 4):S821-S828.

16. Øie, S., J. G. Gambertoglio, and L. Fleckenstein. 1982. Comparison of the disposition of total and unbound sulfisoxazole after single and multiple dosing. J. Pharmacokinet. Biopharm. 10:157-172.

17. Øie, S., T. W. Guentert, and T. N. Tozer. 1980. Effect of saturable binding on the pharmacokinetics of drugs: a simulation. J. Pharm. Pharmacol. 32:471-477.

18. Peterson, L. R., and D. N. Gerding. 1980. Influence of protein binding of antibiotics on serum pharmacokinetics and extravascular penetration: clinically useful concepts. Rev. Infect. Dis. 2:340-348.

19. Reller, L. B., and C. Stratton. 1977. Serum dilution test for bactericidal activity. I. Selection of a physiologic diluent. J. Infect. Dis. 136:187-195.

20. Smyth, R. D., M. Pfeffer, A. Glick, D. R. Van Harken, and G. H. Hottendorf. 1979. Clinical pharmacokinetics and safety of high doses of ceforanide (BL-S786R) and cefazolin. Antimicrob. Agents Chemother. 16:615-621.

21. Stoekel, K., P. J. McNamara, R. Brandt, H. Plozza-Nottebrock, and W. H. Ziegler. 1981. Effect of concentration-dependent plasma protein binding on ceftriaxone kinetics. Clin. Pharmacol. Ther. 29:650-657. 